Forum: Qualitative Social Research, 2000. 1 (2). Art. 21. Retrieved from https://www.qualitative-research.net/index.php/fqs/article/view/1090/2387\# text=Metaphors\%20represent $\% 20$ general\%20cognitive\%20abilities,of\%20und erstanding\% 20 and $\% 20$ self $\% 2$ Ddefinition.

6. Soto Ramírez J. Metáforas, Complejidad y Psicología. Tiempo. Laberinto, 2018. Retrieved from https://xdoc.mx/documents/metaforascomplejidad-y-psicologia-5ec59c9bc7f05

7. Stoddard J, Afari N. The Big Book of ACT Metaphors: A Practitioner's Guide to Experiential Exercises and Metaphors in Acceptance and Commitment Therapy. Oakland: New Harbinger, 2014. 272 p.

8. Stott R, Mansell W, Salkovskis P, Lavender A, Cartwright-Hatton S. Oxford Guide to Metaphors in CBT: Building Cognitive Bridges. Oxford: Oxford University Press, 2010. 260 p.

9. Vega de, M. Introducción a la psicología cognitiva. Madrid: Alianza Editorial, 1998. 568 p.

DOI https://doi.org/10.30525/978-9934-26-073-5-1-47

\title{
TWO MOTIVATIONAL COMMENCEMENT SPEECHES FOR UNDERGRADUATES
}

\author{
Bodnar I. M. \\ Candidate of Philological Sciences, \\ Associate Professor at the Department of Foreign Languages for Sciences \\ Ivan Franko National University of Lviv \\ Solohub L. V. \\ Candidate of Philological Sciences, \\ Associate Professor at the Department of Foreign Languages for Sciences \\ Ivan Franko National University of Lviv
}

\section{Komar R. I.}

Lecturer at the Department of Foreign Languages for Sciences Ivan Franko National University of Lviv Lviv, Ukraine

It is not a secret that people need motivation to perform better - at school, at work or whenever else. The best way to develop yourself is to see someone else's example of success [2, p.4080]. It has been proved that motivated 
behaviors are processed in the brain of people and they can influence cognition, since motivation shapes peoples' thinking [1, p. 62]. Usually the objective of these public speeches is to encourage reflection or influence convictions by appealing to our emotions and inviting us to action. This may be one of the reasons why motivational speeches as art of words and powerful sources of decision making are becoming more and more popular.

Young people nowadays often find themselves on the crossroads of work and study. On the one hand, the society of consumers urges you to start work at an early age. On the other hand, people who devoted their adolescence to proper education, are more successful and compatible on the job market. A life example of a respected dignitary, describing their losses and wins, will probably serve the best motivation for the youngsters. That is why we found the study of motivational discourse very interesting and important.

Thus, current research applies positive discourse analysis to examine the role of public speeches in changing young people's attitude towards (self)education, personal development and confidence-building.

The aim of our survey is to investigate the linguistic and psychological tools of public speeches, namely Commencement ones, and reveal their impact on the recipients, especially the youth.

Two motivational Commencement speeches made by two famous and charismatic Americans, graduates of leading American universities: Steve Jobs (2005) and Mark Zuckerberg (2017) serve as the research material. The two speeches are synchronic in terms of time period and cultural milieu, which makes our study monocultural, or even generalized, when taking into consideration worldwide social status of both speakers. Together, the two speeches are 47.40 minutes long and contain 5816 words.

In the course of study, the following elements of motivational discourse were distinguished: 1) expressing gratitude; 2) sharing own experience; 3) giving instructions based on personal experience; 4) inspiration and encouragement.

Both speakers express implicit gratitude to their family. Not mentioning it directly, the recipient understands that without the support of the closest people, none of them would have been able to overcome the difficulties. Whereas, Zuckerberg says thanks to his alma mater, and most probably he is doing it on purpose, to encourage the undergraduates: "We've all started lifelong friendships here, and some of us even families. That's why I'm so grateful to this place. Thanks, Harvard.» [3].

Life stories of these men have several common features: they both went through failure to reach success. It should be pointed out that both Jobs and Zuckerberg use the technique of narration by telling their own stories. They 
also use the technique of reflection to 'connect the dots', as Steve Jobs calls it. These psychological tricks attract the young audience and eliminate the distance of any kind (social, educational, financial) between them and a welloff celebrity.

Particular of motivational discourse, the speakers are not ashamed of having made mistakes. Vice versa, looking back, they realise that but for the sour experience and persistence, they wouldn't have achieved their aim: "Sometimes life hits you in the head with a brick. Don't lose faith. I'm convinced that the only thing that kept me going was that I loved what I did. You've got to find what you love» [4]. And such 'living' examples inspire young people before a long way. This technique of sharing the experience, usually full of disappointment and struggle, aims to influence the recipients' cognition and make them realise that success is made of hard work and selfconfidence.

Mark Zuckerberg points out that if he had to understand everything about connecting people before he began, heY never would have started Facebook [3]. Because a young person is often deceived by sweet tales of quick and painless success, he wants to warn them not to be deceived: «Movies and pop culture get this all wrong. The idea of a single eureka moment is a dangerous lie. It makes us feel inadequate since we haven't had ours.» [4].

Motivational speeches are conducted by strong and charismatic people, otherwise they would not have an effect on the audience. This is the fact with S. Jobs and M. Zuckerberg: despite all the difficulties they have faced, they are ready to move ahead, and inspire their audience to do the same: «It's up to us to create it so we can all keep moving forward together.» [4].

To create a strong effect on the recipients' minds, the speakers finish their speeches with the words of encouragement, self-belief and self-esteem: «You are graduating into a world that needs purpose. It's up to you to create it. ... I hope you find the courage to make your life a blessing.» [3]; «I have always wished that for myself. And now, as you graduate to begin anew, I wish that for you. Stay Hungry. Stay Foolish.» [4].

To sum up, we have come to the following conclusions. Commencement speeches are aimed at young people with huge ambitions. The aim of the analysed speeches was to warn them about hardships without killing their desire to create and move ahead. Motivational speakers use a set of linguistic and psychological techniques to reach the recipients' cognition. One of the peculiar features of such speeches is their positive tune and attempt to convince the listeners to go directly to the purpose. 


\title{
References:
}

1. Hughes, B. L.; Zaki, J. The neuroscience of motivated cognition. Trends Cogn. Sci. 2015, 19, Pp. 62-64.

2. Sherwani K. A. A Cognitive Positive Discourse Analysis of English Motivational Speeches. International Journal of Advanced Science and Technology. Vol. 29, No. 9s, (2020), Pp. 4078-4091.

3. Mark Zuckerberg's Commencement address at Harvard. Mode of access: Mark Zuckerberg's speech as written for Harvard's Class of 2017 - Harvard Gazette

4. Steve Jobs' 2005 Stanford Commencement address. Mode of access: Text of Steve Jobs' Commencement address (2005) (stanford.edu)

DOI https://doi.org/10.30525/978-9934-26-073-5-1-48

\section{ОСОБЛИВОСТІ ПЕРЕКЛАДУ АНГЛІЙСЬКИХ ФРАЗЕОЛОГІЧНИХ ОДИНИЦЬ ІЗ АНІМАЛІСТИЧНИМ КОМПОНЕНТОМ УКРАЇНСЬКОЮ МОВОЮ}

\author{
Василенко О. М. \\ кандидат психологічних наук, \\ дочент кафедри іноземних мов за професійним спрямуванням \\ Національного педагогічного університету імені М. П. Драгоманова \\ м. Київ, Україна
}

Словниковий склад мови відкритий і постійно змінюється, зокрема іiі одиниці набувають нових значень. У правильності і повноті передачі інформації полягає власне відмінність перекладу від переказу чи скороченого викладу, від будь-якого виду так званих адаптацій. Тому зрозуміло, що можливість правильно передати позначення речей, про які йдеться в оригіналі, і образів, які з ними пов'язані, передбачає наявність певних знань про дійсність, зображену в тексті оригіналу (незалежно від того, чи ці знання надбані шляхом прямого знайомства 3 нею, чи взяті 3 книг або інших джерел). Професор І. Корунець вважає, що засоби перекладу залежать від структури, значення та мовного рівня змістових одиниць. Оскільки переклад є лінгвістичним предметом і він будується на значенні мовних одиниць, то перекладач орієнтується у рівнях цих мовних одиниць [1, с. 179].

У літературі існує багато пропозицій оцінки перекладних еквівалентів. Найбільш переконливою класифікацією еквівалентів в 184 